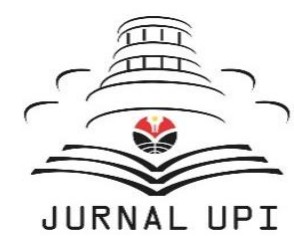

INDONESIAN JOURNAL OF APPLIED LINGUISTICS

Vol. 10 No. 2, September 2020, pp. 481-490

Available online at:

https://ejournal.upi.edu/index.php/IJAL/article/view/28589

https://doi.org/10.17509/ijal.v10i2.28589

\title{
A corpus-based list of academic English derivational suffixes
}

\author{
Suhandoko ${ }^{1}$ and Dian Riesti Ningrum ${ }^{2}$ \\ The English Department, Faculty of Arts and Humanities, UIN Sunan Ampel Surabaya, Jl. A. Yani 117 \\ Surabaya, East Java, Indonesia
}

\begin{abstract}
The study reported in this paper aims to create a list of academic English derivational suffixes to help EFL teachers decide which derivational suffixes to be taught first and help their learners, especially those of higher education, expand their vocabulary size. Gardner and Davies' (2014) 3,000-word list of Corpus of Contemporary American English (COCA) academic was analyzed following Hay (2002) and Plag's (2006) frameworks by counting the number of words containing the suffixes. This study found 1,251 suffixed words in the corpus deriving from 41 suffixes, which comprise 22 noun suffixes, 13 adjectival suffixes, 4 verbal suffixes, and 2 adverbial suffixes. The suffixes were then ordered into 3 levels based on the frequency; 22 suffixes are put in Level 1, 12 suffixes in Level 2, and 7 suffixes in Level 3. Considering the high frequency, all suffixes in Level 1 should gain more attention of the teachers. The more frequent occurrence of the suffix in a variety of context will provide a greater chance for the learners to get more exposure. Hence, mastering it will likely expand learners' vocabulary size through combining the suffix and existing base.
\end{abstract}

Keywords: Academic English; COCA; derivational suffixes

\begin{tabular}{|ccc||}
\hline \hline $\begin{array}{c}\text { First Received: } \\
\text { 20 January 2020 } \\
\text { Final Proof Received: }\end{array}$ & $\begin{array}{c}\text { Revised: } \\
\text { 26 September 2020 }\end{array}$ & $\begin{array}{c}\text { Accepted: } \\
\text { 19 September 2020 } \\
\text { Published: }\end{array}$ \\
\hline $\begin{array}{c}\text { How to cite (in APA style): } \\
\text { Suhandoko \& Ningrum, D. R. (2020). A corpus-based list of academic English derivational } \\
\text { suffixes. Indonesian Journal of Applied Linguistics, 10, 481-490. } \\
\text { https://doi.org/10.17509/ijal.v10i2.28589 }\end{array}$ \\
\hline
\end{tabular}

\section{INTRODUCTION}

Studies have attempted to create an English academic word list based on corpora. However, to the best of our knowledge, previous works have mostly focused on the level ordering (Hay, 2002; Hay \& Plag, 2004), listing suffix word-formation (Montero-Fleta, 2011), and creating a derivational morphological database (Sánchez-Gutiérrez et al., 2018). There is still a need to explore the list of derivational suffixes based on corpora of academic texts. Such a list is considered significant for learners to expand their vocabulary size in the academic context (Saigh \& Sonbul, 2018). By knowing derivational suffixes used in the academic context, learners, especially those of higher education, are benefited in expanding their vocabulary size at the college level and, ultimately, their academic performance involving the use of
English for academic purposes (Choo et al., 2017). Schmitt and Zimmerman (2002) state that although learners can expand their vocabulary size by knowing the derivational suffixes, they do not "absorb the derivative forms of a word family automatically from [the vocabulary] exposure" ( $p$. 163).

In response to this, other studies suggest the enactment of explicit teaching of the derivative forms, such as through introducing the derivative forms when presenting new words, instructing learners by working with word formation, providing shallow but wide, direct instruction and rich but narrow vocabulary instruction, and asking them to memorize the list while raising their awareness of how the suffixes coin new words (see Lin, 2019; Saigh \& Sonbul, 2018; Schmitt \& Zimmerman, 2002). For this reason, the effort to create the list of

\footnotetext{
* Corresponding Author

Email: suhandoko@uinsby.ac.id
} 
the most frequently used derivational suffixes is highly needed. Providing such a list is essential to provide teachers and learners the morphological forms to work with incrementally. This paper aims to investigate types of derivational suffixes that frequently occur in academic texts and to create the frequency-based levels to indicate which suffixes should be taught first to the learners. Creating such levels can aid in the sequencing of teaching (Coxhead, 2000).

Studies have shown that vocabulary plays a significant role in the success of L2 learning (e.g., Ivone, 2005; Mehta, 2009). Due to its significance, Wyra and Lawson (2018) point out that L2 learning should focus on the learners' vocabulary development. Regarding this, a reciprocal relationship between vocabulary knowledge and reading comprehension has been investigated in that vocabulary knowledge is considered a byproduct of or a contributing factor to reading comprehension (see Gardner, 2007; Ma \& Lin, 2015; Nation \& Beglar, 2006; Sidek \& Rahim, 2015). This suggests that vocabulary requires a higher state of attention from teachers. Despite the importance of vocabulary mastery in L2 learning, there remains a puzzle to solve, especially dealing with which vocabulary learners should learn first, or the one which they will most often encounter and use. This also is the case in the context of higher education, where the vocabulary that is taught is different from the everyday one. The vocabulary that is specifically taught and learned in the context of higher education is called the academic vocabulary.

The cataloguing of the academic vocabulary through corpora can be dated back to the 80s when the University Word List (UWL) (Xue \& Nation, 1984) was established. It consists of 836 words commonly found in academic texts but excluded in 2,000 words of West's General Service List or GSL (1953). Compared to West's GSL, learning UWL even before studying at university is beneficial for learners. They will be more quickly and confident to master the materials written in English, and not wasting time guessing vocabulary or consulting a dictionary (Valcourt \& Wells, 1999). However, Xue and Nation's UWL is considered unreliable due to inconsistencies in the vocabulary selection, in which they only edited and combined different vocabulary lists (Coxhead, 2000). This encouraged Coxhead to create a new vocabulary list divided into "frequency-based sublists" (Coxhead, 2000, p. 214) called Academic Word List (AWL).

The AWL, which is arranged based on corpora in four disciplines (commerce, science, arts, and law), provides very useful information about what vocabulary is best to teach first to the learners and helps them predict the appearance of particular vocabularies in academic texts (Coxhead, 2000). The AWL contains 570-word families, which account for $10 \%$ of the tokens in academic corpora and "constitutes a specialized vocabulary with good coverage of academic texts" (Coxhead, 2000, p. 226).

Although Coxhead's AWL is considered better as an academic vocabulary standard list compared to other similar lists, there are two things that Gardner and Davies (2014) considered problematic about it i.e. "the use of word families to determine word frequencies, and the relationship of the AWL with the GSL" (p. 307). These then motivated them to create the Academic Vocabulary List (AVL) using a more robust methodology. The list was derived from the academic texts, comprising 120 million words available in the Corpus of Contemporary American English (COCA).

The AVL is composed of 120 million words contained in COCA covering nine disciplines: education, humanities, history, social science, law and politics, philosophy and religion, natural sciences and technology, medicine and health, and business and finance (Gardner \& Davies; 2014). The fundamental difference between AVL and AWL is the word selection technique. Words in AWL are selected based on word family, while AVL grounds its selection criteria on lemma. Gardner and Davies (2014) argue that the use of the word family in word selection process will lead to a severe problem in that the same word but in different word class categories will be counted as a word family. However, if the two words are counted based on the lemma, each is counted as a different individual. They give examples of the words proceeds (noun), proceeds (verbs), proceedings (noun), procedural (adjective), procedures (noun) to be included in one-word family proceed, but in Gardner and Davies' (2014) AVL, they are counted on their own.

Looking at the enthusiasm of scholars in creating the academic vocabulary lists as elaborated above, it seems evident that the knowledge of which can help learners improve their analytical and inferential skills in discipline-based productive and receptive skills (Marzano \& Pickering, 2005). Furthermore, the knowledge and understanding of the use of AVL can build students' confidence when dealing with a variety of materials, such as journal articles, books, and other academic publications. This is evident in the results of Choo and colleagues' study (Choo et al., 2017) in a Malaysian tertiary education setting. The study reported that the knowledge of AVL has enhanced not only the ability of Malaysian tertiary students in academic writing but also the ability of public speaking, especially in academic presentations, as well as listening to lectures. Hence, the study suggests that English teachers and curriculum developers consider teaching AVL explicitly and extrinsically to improve learners' academic vocabulary size.

However, problems arise in the attempts to explicitly teach the vocabulary, especially relating to the demand to memorize a large amount of 
vocabulary to learn. Studies have been conducted to provide strategies to increase academic vocabulary size. Some studies recommend using technologies such as social media, text message services, and online-based videos (e.g., Alemi et al., 2012; Kabilan \& Zahar, 2016; Lin, 2018; Vaughn et al., 2009), embedding academic vocabulary in receptive and productive tasks and interactive, hands-on tasks (e.g., Cao, 2013; Ghorbani, 2012; Kelley et al., 2010; Larson et al., 2013; Shabanpour \& Marxban, 2015), and including academic vocabulary in L2 instruction both incidentally and intentionally (e.g., Arechiga, 2012; Gallagher et al., 2019; Helman, 2015; Schmitt, 2007). However, despite the success of the implementation, few have shown that they effectively promote the acquisition and retention of academic vocabulary (Douglas, 2016). Vocabulary knowledge can be described as either through the dimension of size (breadth) and/or production (AlHomoud, 2007). In order to increase vocabulary size, one strategy is to recognize derivational affixes. By introducing derivational affixes, teachers can introduce the word "by teaching word families instead of individual word forms" (Schmitt, 2007, p. 163). Hence, with the knowledge of derivational affixes through explicit teaching, learners can expand their academic vocabulary size from a base.

In the learning of vocabulary, derivational affixes should always be taken into account. While explicit instruction of derivational affix has been proven to be effective in expanding learners' vocabulary size (Morin, 2003; Schmitt, 2014), teachers, however, frequently neglect the importance of teaching derivational affix due to the scarcity of textbooks that specifically discuss it and the irregular nature of word formation that makes it a tough challenge for learners to learn, let alone master it (Brown, 2010). A derivational affix is an affix which changes the type of meaning of a base (Plag, 2003). Thus, it functions to create new words. Knowing derivational affixes is important for learners because it can help them expand their vocabulary size (Nation, 2001; Saigh \& Sonbul, 2018; Schmitt, 2014; Schmitt \& Zimmerman, 2002). For example, if learners know the derivational suffix -ment, which changes a verb into a noun, they can multiply their vocabulary inventory when they only know three words: develop, govern, and engage. With that derivational suffix, their vocabulary inventory expands into six words, i.e., develop, development, govern, government, engage, and engagement. For this reason, scholars affirm that teaching derivational affixes can be a significant factor in equipping comprehension and assuring that learners have a clear understanding of the vocabulary (Saigh \& Sonbul, 2018).

A consensus has been reached that derivational comes after inflectional morphology (Saigh \& Sonbul, 2018; Schmitt \& Zimmerman, 2002). In contrast to inflectional affixes where the word class of its stem will change, and the location and meaning of the affixes in a word are predictable (i.e., -s/-es is always required to be added at the end of the verb when the subject is 3rd person singular in present simple), derivational affixes typically produce different word class and meanings (i.e., differ [verb] $\rightarrow$ different [adjective]) and are not always governed with consistent and transparent rules. It is what concerns Schmitt and Zimmerman (2002) that "a considerable portion of a learner's lexicon may remain unused due to the lack of requisite knowledge of derivation" (p. 165).

In the Cambridge Grammar of English (CGE), Carter and McCarthy (2006) mention 37 prefixes and 45 suffixes used in English, deriving from Germanic, Latin, Greek, and French (Culpeper, 2005; Trevian, 2015). This study focused on creating the list of derivational suffixes in the academic word list because "they play a more prominent role than do prefixes in English word formation" (Nishimoto, 2004, p. 1024). Furthermore, studies (e.g. Hay, 2002; Hay \& Plag, 2004; Montero-Fleta, 2011; Sánchez-Gutiérrez et al., 2018) have been conducted on investigating the productivity of English affixes. An affix is considered to be productive or frequent if it is likely available for creating new words (Bauer \& Nation, 1993; Huddleston, 2002) and, hence, mastering it will likely expand vocabulary size because highfrequency morphology can be accessed more quickly and produced more fluently (Hay, 2002; Nation, 2001; Saigh \& Sonbul, 2018). However, studies focusing on creating the list of derivational suffixes from the academic word list have yet significantly been conducted. Against those reasons, the study reported in this paper aims at determining the derivational suffixes that frequently occur in academic texts. Also, this study would set the levels of suffixes based on their frequencies, indicating which ones should be taught first according to the corpus linguistics point of view.

\section{METHOD}

The study focused on the analysis of derivational suffixes taken from Gardner and Davies' (2014) 3,000-word list of Corpus of Contemporary American English academic (COCA academic) containing 3,000 lemmata. A lemma (pl. lemmata) consists of a headword and some of its inflected and reduced ( $n^{\prime} t$ ) form (Nation, 2001). COCA academic was arranged in the order of frequency data from the corpus. They put the most frequent words found in the corpus in the high-frequency list, while the least in the low-frequency list. Following this framework, this study arranged the suffixes based on their occurrence in COCA academic. In order to measure the frequency of the suffixes, the number of words containing the suffixes is calculated (Hay, 2002; Plag, 2006). For example, -at(ion) was found in 167 
words in COCA academic, making it the noun suffix with the highest frequency of occurrence. On the other hand, -ician was found to coin one word, making it the noun suffix with the lowest frequency of occurrence.

In order to help teachers and learners decide the suffix to work with first, providing the levels of the suffix will help them create "the basis for the staged systematic teaching and learning" (Bauer \& Nation, 1993, p. 254). This study distributed the division of suffix into three levels $(1,2$, and 3$)$ with the focus on frequency. The size of frequency included in each level was determined arbitrarily, and no theoretical value was considered. Noun suffixes were distributed into three levels $(1,2$, and 3 ) merely because there are many types of them in the corpus (22 noun suffixes), and 13 adjectival suffixes were distributed in two levels (1 and 2). The verbal and adverbial suffixes, however, were only distributed in Level 1 because they are not abundant in the corpus. This distribution of levels will help teachers and learners to focus on the suffixes in Level 1 first, and the ones in Level 2 and 3 later (Coxhead, 2000).

The data in this study were collected from COCA academic downloaded from http://www.academicvocabulary.info. Following downloading the list, the steps of data analysis are as follow. The first step was to check manually each of the 3,000 lemmata which have derivational affixes. The second step was sorting the words and dividing them into two groups: prefixed and suffixed words. At this step, there were 1,251 suffixed words found on the list. The third step was the validity checking. In this step, the validity of each suffixed word and its base were checked by consulting Carter and McCarthy's CGE (2006) and the Oxford Advanced Learner's Dictionary (OALD, $9^{\text {th }}$ ed., 2015). For instance, to check the base form and the suffix of the word garment, a dictionary check on the word gar was carried out since it can be assumed that garment contains -ment, which can only be attached to verbs. The result showed that gar is not an English word. Therefore, garment is not a word with -ment. The last step was counting the number of suffixes and formulating the level of the suffixes. In formulating the level of suffixes, all suffixes used in English were divided arbitrarily into three levels, based on their frequencies.

\section{FINDINGS AND DISCUSSION}

This study found 1,251 suffixed words in COCA academic. These words were derived from 41 suffixes: 22 noun suffixes, 13 adjectival suffixes, 4 verbal suffixes, and 2 adverbial suffixes. The discussion of findings in this section is organised into four general headings, following types of suffixes mentioned previously.

\section{Noun suffixes in COCA academic}

In CGE, Carter and McCarthy (2006) mention 21 noun suffixes, three of which were not found in this study. They are -dom, -hood, and -let/-ette. However, four other suffixes that are not listed in CGE were found. They are -acy/-cy, -ician, $-s$, and ure. They were then altogether categorized into three levels: 9 suffixes in Level 1, 6 in Level 2, and 7 in Level 3.

Table 1 illustrates the frequency of noun suffixes included in Level 1 followed by the sample of words with ranks in the corpus. For example, at(ion) occurs 167 times. The sample of the words are interpretation, which is ranked $313^{\text {th }}$, and integration ranked $511^{\text {th }}$ in the academic corpus. Also, it can be seen that non-Germanic suffixes, such as -(at)ion, -ity/-ty, -sion/-tion/-xion, -ance/ence, -ment, -acy/-asy/-cy, and -ist have high frequency of occurrence on the list with 167, 88, 88, $59,43,24$, and 19 respectively, while Germanic suffixes, such as -ar/-er/-or and -ness occur 31 and 22 times respectively. While Bauer and Nation (1993) consider -ion different from -(at)ion, Carter and McCarthy (2006) consider them the same because they come from the same root, making it more productive because two variants are considered as one.

Table 1

Level 1 of Noun Suffixes in COCA Academic

\begin{tabular}{lcl}
\hline Noun Suffixes & Frequency & Sample of Words (Rank) \\
\hline -(at)ion & 167 & interpretation (313), integration (511) \\
-ity/-ty & 88 & availability (753), sustainability (1182) \\
-sion/-tion/-xion & 88 & expansion (569), erosion (984) \\
-ance/-ence & 59 & significance (449), reliance (1121) \\
-ment & 43 & adjustment (542), endowment (1406) \\
-ar/-er/-or & 31 & practitioner (633), reformer (1325) \\
-acy/-asy/-cy & 24 & advocacy (962), idiosyncrasy (2758) \\
-ness & 22 & weakness (786), richness (1497) \\
-ist & 19 & naturalist (1846), interventionist (2616) \\
\hline
\end{tabular}

Furthermore, the Latinate -(at)ion is commonly put after verbs ending with -ate, -ify, or -ize, which were found to be frequent verb suffixes in COCA academic (see verbal suffixes in COCA academic section), as in interpretation, purification and realization. The Latinate -ity/-ty was found 88 times as in familiarity and inability. This suffix is only suitable to end Latinate word base (Trevian, 2015), 
for example, familiar from Latin familiaris and able from Latin habilis.-acy/-asy/-cy with 24 occurrences in the corpus and -ist with 19 occurrences. Both suffixes are orthographically regular, making it perfect to be included in Level 1 of academic English derivational suffixes. -acy/-asy/-cy creates nouns of quality, state, condition, or function, which is now rarely used in coining nouns and is displaced with other variants, such as -ace, -ice, -ity, -ness and -(at)ion (Trevian, 2015). This suffix, however, was not mentioned in Bauer and Nation's (1993) list probably because it has not produced new nouns and has been included in the extinct suffixes (Trevian, 2015). Another non-Germanic noun suffix is -ist which denotes an agent, a doer, or a believer. (1993) put this suffix in the Level 3 out of 7 levels set.

Table 2 displays eight noun suffixes included in Level 2 in COCA academic. The suffix -al ranks in the first place, which functions to form nouns from verbs. It occurs ten times, for example, in the word reversal and portrayal. In the second place, the suffix -ism appears nine times. Examples of words that include -ism are antagonism and paternalism.

In the Level 2 noun suffixes, -ary/-ery/-ory occurs seven times as in functionary, imagery, and directory. Quinion (2008) suggests that in order to form a word that reflects a person associated with an activity, -ary can be added as in secretary. He also adds that -ery denotes kind of an object as in crockery and scenery and marks the places where an activity is carried on as in bakery and nursery. As for other words such as archery and slavery, the suffix -ery indicates occupations, states or conditions. Another function of the suffix -ery is to form nouns denoting a place set aside for an activity or to keep animals as in piggery and rookery.

Table 2

Level 2 of Noun Suffixes in COCA Academic

\begin{tabular}{lll}
\hline Nouns Suffixes & Frequency & Sample of Words (Rank) \\
\hline -al & 10 & reversal (1330), portrayal (1485) \\
-ism & 9 & antagonism (2007), dynamism (2231) \\
-ary/-ery/-ory & 7 & functionary (2764), imagery (829) \\
-(r)y & 6 & intermediary (1806), inquiry (2785) \\
-ship & 5 & ownership (747), stewardship (1863) \\
-ure & 5 & expenditure (865), nomenclature (2532) \\
\hline
\end{tabular}

Ranked the third in Level 2 is the suffix $-r(y)$, with six occurrences. Stockwell and Minkova (2001) state that $-r(y)$ functions to get abstract nouns from concrete nouns reflecting collectivity as in entry and intermediary. In the fourth place, the suffix-ship occurs five times, as in interrelationship and membership. Similar to -r(y), -ship also forms an abstract noun from concrete nouns (Stockwell \& Minkova, 2001). Moreover, Quinion (2008) clarifies that -ship denotes a quality or condition as in friendship and worship and signifies status and rank as in ambassadorship and kingship. Further, Quinion (2008) adds that -ship indicates a skill as in entrepreneurship and authorship and also denotes a collection of individuals as in membership and viewership.

In conclusion, the suffixes which belong to the Level 2 noun suffixes in COCA academic are - $a l$, ism, -(r)y, -ary/-ery/-ory, -ship, and -ure.

Table 3 displays noun suffixes in COCA academic that belong to Level 3, among others are s, -age, -ant/-ent, -ie/-y, -hood, -ee, and -ician with four, three, or one occurrence(s) in range. Despite their orthographic regularity that makes it easier for learners to memorize and use when creating new words, the suffixes were less likely found in academic corpus. In addition, three noun suffixes are listed in Carter and McCarthy's CGE (2006) but not found in the corpus, namely-arium/-orium, - dom, and -let/-ette. Culpeper (2005) reported that since the seventeenth century, English borrowing from Latin as the language of scholarship and scholarly literature has been in decline. Therefore, some non-Germanic suffixes are rare now and have undergone significant extinction (Culpeper, 2005). Due to their low frequency of occurrence, the chances for learners to meet the vocabulary ended with these suffixes (in Level 2 and 3), at least in the context of academic, is smaller in size. Pedagogically, this impacts on the less importance of teaching these suffixes in the early stages of learning. Hence, explicit, but incidental instruction might benefit teachers and learners (Schmitt, 2007), meaning that explicit teaching of the semantic and syntactic functions of the suffix will be the starting point of presenting the suffix to the learners. Once they get into the habits of recognizing constituent parts of the words, they will eventually make effective connections between words incidentally in context. For example, in addition to the explicit instruction of the target suffixes, teachers can provide learners with a variety of texts at an appropriate level with the targeted words highlighted (e.g., in bold or colored). Teachers can also read the text aloud as the students followed along to provide more exposure to the target words (Gallagher et al., 2019). Table 3 shows the third level of noun suffixes in COCA academic 
Table 3

Level 3 of Noun Suffixes in COCA Academic

\begin{tabular}{lcl}
\hline Noun Suffixes & Frequency & Sample of the Words (Rank) \\
\hline -s & 4 & dynamics (630), economics (677) \\
-age & 4 & passage (479), linkage (1105) \\
-ant/-ent & 4 & descendant (1185), applicant (1113) \\
-ie/-y & 3 & analogy (1001), difficulty (296) \\
-hood & 3 & adulthood (1310), likelihood (763) \\
-ee & 1 & attendee (1866) \\
-ician & 1 & academician (2652) \\
\hline
\end{tabular}

\section{Adjectival suffixes in COCA academic}

In CGE, Carter and McCarthy (2006) mention 17 adjectival suffixes, seven of which (-ese, -en, -ish, $i$, -like and -type) were not found in COCA academic because they are not common in academic English vocabulary (Kinsella, 2013). However, this study found three suffixes (-y, -ate, -ory/-ary) which are not listed in Carter and McCarthy's CGE (2006) because they are not common in present-day English but mentioned in Stockwell and Minkova' (2009) English Words: History and Structure.

Table 4 illustrates the frequency of the adjectival suffixes in the academic corpus. From the table, it can be seen that the most frequent adjectival suffixes, except for Germanic's -ful, are Latinate. This strengthens the findings in this study that nonGermanic suffixes appear to be typical in academic
English. The high frequency of occurrence of these suffixes implies the importance of teaching them to the learners at the early stages of learning to enable them to understand the nature of the suffix more deeply and avoid fossilization (Saigh \& Sonbul, 2018; Schmitt \& Zimmerman, 2002).

Suffixes such as -al/-ial/-ual, with the highest occurrences in the corpus, should be the priority to teach, especially when teaching how to create adjectives by combining the suffix and base. Bauer and Nation (1993) categorize the suffix as frequent and orthographically regular, making it perfect to be included in Level 1 and taught first to the learners. Similarly, the suffixes -able/-ible, -ous and -ful are also categorized as the frequent and orthographically regular suffixes with 98,25 , and 14 occurrences, respectively.

Table 4

Level 1 of Adjectival Suffixes in COCA Academic

\begin{tabular}{lcl}
\hline Adjectival Suffixes & Frequency & Sample of the Words (Rank) \\
\hline -al/-ial/-ual & 184 & cultural (79), influential (862) \\
-ive & 105 & relative (506), extensive (538) \\
-able/-ible & 98 & reliable (751), sustainable (817) \\
-ic & 79 & strategic (514), electronic (565) \\
-ary/-ory & 29 & disciplinary (1295), supplementary (2013) \\
-ous & 25 & synonymous (1888), erroneous (1916) \\
-ful & 14 & successful (246), useful (342) \\
\hline
\end{tabular}

The findings corroborate Montero-Fleta (2011) that these four suffixes frequently occur in scientific English. Plag (2006) argues that the greater the frequency of occurrence of the suffix, the more productive it is. This means that the suffixes are likely to be used to create new words (Bauer \& Nation, 1993). Considering that the suffixes can be found a lot in academic texts, learners can potentially expand their vocabulary size by coining new words from existing base using the suffixes.

In addition to suffixes that are frequent in terms of occurrence and orthographical regularity, Bauer and Nation (1993) categorize suffixes, such as -ive and -ic, into frequent but orthographically irregular. Both suffixes occur in incredibly high frequency, with 105 and 78 occurrences, respectively. Despite their unproductivity in creating new words since the peak of the Renaissance, -ive are potentially active now, especially in scientific vocabulary (Trevian, 2015) because it is generated from noun suffix -ion through conversion, as in relative (<relation) and comprehensive (<comprehension). The same case applies to -ic, which is orthographically irregular. Its productivity is also supported by the fact that it is usually combined with other suffixes, as in historical $(i c+a l)$, gratification (ic +ation), multiplicity (ic $+i t y)$ and paternalistic (ist $+i c)$. Considering this, these suffixes are highly productive; therefore, teachers should consider putting them on the top list of derivational suffix instruction.

In addition to seven suffixes included in Level 1 , six other adjectival suffixes were also found in the corpus and included in Level 2 due to their infrequent occurrences, as shown in Table 5.

Table 5 describes the least frequent suffixes in COCA academic. They are -ian/-an, -ate, -ly, -less, $e d$, and $-y$ with occurrences ranging from two to five. Despite their orthographical regularity (Bauer \& Nation, 1993), the suffixes are found to be less frequent, hence less productive. This can be shown that in 553 suffixed adjectives, the suffixes were only found to occur 19 times, less than one percent. This is in line with Plag (2006), who asserts that the 
case in which all regular inflections seem to be fully-productive does not apply to derivatives.

In general, adjectives and adverbs are the least likely members of a word family to be known, especially in the academic context, but a bit more difficult to learn (Schmitt \& Zimmerman, 2002). Therefore, teachers might need to emphasize the explicit instruction of them logically by paying attention to the extent the learners benefit the instruction. One way is to prioritize the suffixes that are likely to be found in various contexts.

\section{Verbal suffixes in COCA academic}

There are four verbal suffixes found in COCA academic, including -ise/-ize, -ate, -ify, and -en, as shown in Table 6.

Table 5

Level 2 of Adjectival Suffix in COCA Academic

\begin{tabular}{lll}
\hline Adjectival Suffixes & Frequency & Sample of Words (Rank) \\
\hline -ian/-an & 5 & Asian (520), Darwinian (2193) \\
-ate & 4 & disproportionate (1692), proportionately (2603) \\
-ly & 3 & timely (1364), scholarly (983) \\
-less & 3 & powerlessness (2405), hopelessness (2287) \\
-ed & 2 & skilled (991), detailed (592) \\
-y & 2 & cursory (2452), noteworthy (1503) \\
\hline
\end{tabular}

Table 6

Verbal Suffixes in COCA Academic

\begin{tabular}{lcl}
\hline Verbal Suffixes & Frequency & Sample of Words (Rank) \\
\hline -ise/-ize & 53 & maximize $(980)$, internalize (1471) \\
-ate & 10 & designate $(1192)$, substantiate $(1954)$ \\
-ify & 6 & typify $(2097)$, purify $(2203)$ \\
-en & 5 & broaden $(1300)$, lessen $(1477)$ \\
\hline
\end{tabular}

As shown in Table 6, there are four verbal suffixes coining 74 suffixed words in COCA academic. The findings are consistent with that of Carter and McCarthy's (2006) CGE that the suffixes are commonly combined with base forms in coining verbs. The suffix -ise/-ize, with 53 occurrences, ranks the first in the most frequent verbal suffix. It functions to describe something or treat it in a given way and takes the position as a direct object in a sentence as in computerize and sterilize. It also means action, behavior, practice, or policy as in moralize and theorize. On the other hand, the suffix -en, with only five occurrences, ranks the last on the list. This is plausible because -ize can be easily adjoined to adjectives and nouns to create new verbs. There are 284 new verbs in -ize created between 1900 and 1985, but no new verbs in -en has been coined since 1900 (Plag, 2004). This implies that -ize/-ise should gain more attention in L2 instruction, especially during the introduction of verbal suffixes; while -en can be taught the last.

The Latinate -ate and -ify, with only ten and six occurrences respectively on the list, are the most productive suffix in Modern English (Quinion,
2008). The suffix -ate is categorized as an irregular suffix because readers need to differentiate various functions of it such as to form nouns as in doctorate, adjectives as in passionate, and to form verbs as in designate. Considering this, teachers should instruct the suffix to the learners explicitly but with a "healthy dose of cautions" (Schmitt \& Zimmerman, 2002, p. 164) because it can be deceptive that incorrect misunderstanding of the suffix can lead to inaccurate forms and functions. Likewise, the suffix -ify is commonly associated with the words ending in -fic and -fication as in satisfaction and identification. In addition to explicit instruction of the derivational suffixes, it seems to be beneficial to recommend the learners academic reading (Schmitt \& Zimmerman, 2002) to give them more exposure to the target suffixes.

\section{Adverbial suffixes in COCA academic}

Carter and McCarthy's (2006) CGE mentions three adverbial suffixes: $-l y,-\operatorname{ward}(s)$, and -wise. The present study, however, only found two of which, ly and -wise as shown in Table 7.

Table 7

Adverbial Suffixes in COCA Academic

\begin{tabular}{lcl}
\hline Verbal Suffixes & Frequency & Sample of Words (Rank) \\
\hline -ly & 240 & implicitly (1358), appropriately (1188), \\
-wise & 1 & likewise (733) \\
\hline
\end{tabular}

Table 7 shows that $-l y$ is the most frequently occurring adverbial suffix in COCA academic. The suffix -ly can be attached to adjectives to form adverbs in two ways: directly to adjective as in carefully and to words ending in a vowel $(-y)$ requiring $-y$ change to $-i$ before adding $-l y$ as in 
easily (easy+ly) (Trevian, 2015). The suffix satisfies the criteria of frequency, productivity, and regularity, making it suitable to be put at the top list of adverbial suffixes that must be taught first to the learners. Ranked the second, the adverbial suffix wise occurs only once in the corpus. Quinion (2008) states that this suffix is taken from -ways and signifies relations between one entity to the other as in edgeways and edgewise and in crossways and crosswise. Due to its infrequent occurrence, teachers can teach the word as a whole word rather than in decomposition. The adverbial suffix that was not found in this study is - $\operatorname{ward}(s)$. This suffix, although usually resembling the same characteristics of being adjectives as in "The location of tribal populations in backward areas, stark inequalities" or of being nouns as in "the two began planning operations to the nortward", is considered an adverb in the British English; while in American English, it tends to be categorised as adjective, noun, and adverb in American English (Carter \& McCarthy, 2001). Once again, the most frequent suffixes in COCA academic should gain more attention of the teachers when considering expanding learners' vocabulary size by combining the suffixes and existing base.

\section{CONCLUSION}

This paper has reported result of a study focusing on describing the list of derivational suffixes that frequently occurs in academic text, as well as creating levels of such to help teachers determine which suffixes that need to be taught first. In the study, 1,251 suffixed words were found from COCA academic. They comprise 41 suffixes, among which are 22 noun suffixes, 13 adjectival suffixes, 4 verbal suffixes, and 2 adverbial suffixes. These suffixes were then classified into three levels based on their frequency of occurrence. There are 22 suffixes in Level 1, 12 suffixes in Level 2, and 7 suffixes in Level 3.

This study found that non-Germanic suffixes, especially the Latinate, French, and Greek, are typical derivational suffixes in academic English. Among which, noun suffixes -(at)ion, -ity/-ty, sion/-tion/-xion, and -ance/-ence, adjectival suffixes -al/-ial/-ual, -ive, -able/ible, and -ic, verbal suffixes -ise/ize and -ate, and adverbial suffix -ly are the most frequent in the academic corpus. Considering that they are high in frequency, these suffixes should be taught first to the learners. The more frequent the suffixes used in creating new words, the more likely the learners meet and get exposed to them. Once the learners memorize, understand, and use the suffixes in creating new words, they will have a greater chance to expand their vocabulary size (Saigh \& Sonbul, 2018).

Since the study reported in this paper takes frequency into account, there are some limitations, especially dealing with the criteria of level ordering.
Specifically, this study only focuses on the frequency of each suffix in level ordering, thus disregarding other criteria (see Bauer and Nation, 1993). Excluding regularity analysis in level ordering might cause the difficulty in learning the suffix because more understanding of the generative nature of suffixes is required. However, regularity analysis, and other criteria as well, were considered unnecessary in this study by considering that the suffixes frequently occurring in COCA academic were found to be regular. Despite the limitation of criteria used in the level ordering, this study is still significant because, in addition to the fact that the data was taken from COCA academic which is always updated every five years, the results of this study potentially contribute to the teaching of vocabulary. This study provides the list of the most frequent suffixes in any texts in the current years; therefore, it can serve as a guide for teachers, and possibly material developers, regarding which suffix to introduce first to the learners.

There are some pathways that can be taken for future investigation reflecting on the result reported in this paper. Further investigation is recommended to look at, for example, the extent to which this level of suffixes works in broadening and enriching learners' vocabulary through classroom experimentation. In addition, it is hoped that the results of the study can be taken into account to extend and integrate research on the differences between derivational suffixes in English and other languages, then applying it to the language learners as well. More importantly, the results of this study can be used as a guideline in developing English proficiency test.

\section{REFERENCES}

Alemi, M., Sarab, M. R. A., \& Lari, Z. (2012). Successful learning of academic word list via MALL: Mobile assisted language learning. International Education Studies, 5(6). https://doi.org/10.5539/ies.v5n6p99

Al-Homoud, F. (2007). EFL learners' receptive and productive knowledge of word derivatives. International Journal of English Language and Linguistics Research. 5(2), 43-56.

Arechiga, D. (2012). Four key ways to help English language learners improve their academic vocabulary. Eye on Education.

Bauer, L., \& Nation, P. (1993). Word families. International Journal of Lexicography, VI, 253-279. https://doi.org/10.1093/ij1/6.4.253

Brown, D. (2010). What aspects of vocabulary knowledge do textbooks give attention to? Language Teaching Research, 15(83), 83-97. https://doi.org/10.1177/1362168810383345

Cao, Z. (2013). The effects of tasks on the learning of lexical bundles by Chinese EFL learners. 
TPLS Theory and Practice in Language

Studies, 3(6), 957-962.

https://doi.org/10.4304/tpls.3.6.957-962.

Carter, R., \& McCarthy, M. (2006). Cambridge grammar of English. Cambridge University Press.

Choo, L. B., Lin, D. T. A., Singh, M. K. M., \& Ganapathy, M. (2017). The significance of the academic word list among ESL tertiary learners in a Malaysian public university. $3 L$ The Southeast Asian Journal of English Language Studies, 23(4), 56-65. https://doi.org/10.17576/31-2017-2304-05

Coxhead, A. (2000). A new academic word list. TESOL Quarterly, 31(2), 213-238. https://doi.org/10.2307/3587951

Culpeper, J. (2005). History of English. London: Routledge.

Douglas, V. (2016). Enhancing English academic vocabulary acquisition and retention in intensive English programs with the involvement load hypothesis. Theory and Practice in Language Studies, 6(12), 2237. https://doi.org/10.17507/tpls.0612.01

Gallagher, M. A, Barber, A. T., Beck, J. A., \& Buehl, M. M. (2019). Academic vocabulary: Explicit and incidental instruction for students of diverse language backgrounds. Reading \& Writing Quarterly, 35(2), 84-102 doi: 10.1080/10573569.2018.1510796

Gardner, D. (2007). Validating the construct of word in applied corpus-based vocabulary research: A critical survey. Applied Linguistics, 28(2), 241-265. https://doi.org/10.1093/applin/amm010

Gardner, D. \& Davies, M. (2014). A new academic vocabulary list. Applied Linguistics, 35(3), 305-327. htps://doi.org/10.1093/applin/amt015

Ghorbani, M. (2012). Study of the relationship between cultural intelligence and organizational effectiveness in Esfarayen industrial complex of Iran. African Journal of Business Management, 6(4). https://doi.org/10.5897/ajbm11.2121

Hay, J. B. (2002). From speech perception to morphology: Affix-ordering revisited. Language, 78, 527-555. https://doi.org/10.1353/lan.2002.0159

Hay, J. B., \& Plag, I. (2004). What constrains possible suffix combinations? On the interaction of grammatical and processing restrictions in derivational morphology. Natural Language \& Linguistic Theory, 22(3), 565-596. https://doi.org/10.1023/b:nala.0000027679.633 08.89

Helman, A. L. (2015). The clues strategy: Improving science vocabulary acquisition for secondary English language learners with reading disabilities [Doctoral dissertation,
Lehigh University]. Lehigh Preserve http://preserve.lehigh.edu/etd/2631

Huddleston, R. (2002). The Cambridge grammar of the English language. Cambridge University Press.

Ivone, F. M. (2005). Teaching English as a foreign language in Indonesia: The urge to improve classroom vocabulary instruction. TEFLIN Journal, 16(2). http://journal.teflin.org/index.php/journal/articl e/view/74

Kabilan, M. K., \& Zahar, T. Z. M. E. (2016). Enhancing learners' vocabulary knowledge using the facebook environment. Indonesian Journal of Applied Linguistics, 5(2), 217. https://doi.org/10.17509/ijal.v5i2.1346

Kelley, J. G., Lesaux, N. K., Kieffer, M. J., \& Faller, S. E. (2010). Effective academic vocabulary instruction in the urban middle school. The Reading Teacher, 64(1), 5-14. https://doi.org/10.1598/rt.64.1.1

Larson, L., Dixon, T., \& Townsend, D. (2013). How can teachers increase classroom use of academic vocabulary? Voices from the Middle, 20(4). https://secure.ncte.org/library/NCTEFiles/Reso urces/Journals/VM/0204may2013/VM0204How.pdf

Lin, A. T. W. (2018). Improving the academic vocabulary of tertiary learners through direct vocabulary instruction with gamification [Doctoral dissertation, Wawasan Open University]. http://woulibrary.wou.edu.my/thesesproject/PhD2018_WLTAN.pdf

Lin, M. (2019). Developing EFL learners' morphological awareness: Instructional effect, teachability of affixes, and learners' perception. International Review of Applied Linguistics in Language Teaching, 57(3), 289325. https://doi.org/10.1515/iral-2015-0081

Ma, Y., \& Lin, W. (2015). A study on the relationship between English reading comprehension and English vocabulary knowledge. Education Research International, 2015, 1-14. https://doi.org/10.1155/2015/209154

Marzano, R. J. \& Pickering, D. J. (2005). Building academic vocabulary: Teachers manual. Alexandria, VA: Association for Supervision and Curriculum Development.

Mehta, N. K. (2009). Vocabulary teaching: Effective methodologies. The Internet TESL Journal, XV. http://iteslj.org/

Montero-Fleta, B. (2011). Suffixes in wordformation processes in scientific English. LSP Journal, 2(2). https://rauli.cbs.dk/index.php/lspcog/article/vie w/3356 
Morin, R. (2003). Derivational morphological analysis as a strategy for vocabulary acquisition in Spanish. Modern Language Journal, 87(2), 200-221. https://doi.org/10.1111/1540-4781.00186

Nation, P. (2001). Learning vocabulary in another language. Cambridge University Press.

Nation, P., \& Beglar, D. (2006). A vocabulary size test. The Language Teacher, 31(7), 9-13. https://doi.org/10.26686/wgtn.12552197

Nishimoto, E. (2004). Defining new words in corpus data: Productivity of English suffixes in the British National Corpus. Proceedings of the 26th Annual Meeting of the Cognitive Science Society (CogSci 2004), Chicago, USA (August 2004). https://escholarship.org/uc/item/6m33v208

OALD 9th. (2015). Oxford advanced learner's dictionary (9th ed.). Oxford University Press.

Plag, I. (2003). Word-formation in English. Cambridge University Press.

Plag, I. (2006). Productivity. In Aarts, B., \& McMahon, A. M. (Eds). The handbook of English linguistics (pp. 537-556). Blackwell.

Quinion, M. (2008). Affixes: The building blocks of English. Index. Retrieved June 17, 2017 from http://affixes.org/c/com-.html

Saigh, K., \& Sonbul, S. (2018). Teaching prefixes and suffixes. In J.I. Liontas, T. International Association, \& M. DelliCarpini (eds.) The TESOL Encyclopedia of English Language Teaching. https://doi.org/10.1002/9781118784235.eelt07 79

Sánchez-Gutiérrez, C. H., Mailhot, H., Deacon, S. H., \& Wilson, M. A. (2018). Morpholex: A derivational morphological database for 70,000 English words. Behavior Research Methods, 50(4), 1568-1580. https://doi.org/10.3758/s13428-017-0981-8.

Schmitt, N. (2007) Current perspectives on vocabulary teaching and learning. In: Cummins J., Davison C. (eds) International handbook of English language teaching (pp. 827-841). Springer.

Schmitt, N. (2014). Size and depth of vocabulary knowledge: What the research shows. Language Learning, 64(4), 913-951. https;//doi.org/10.1111/lang.12077
Schmitt, N., \& Zimmerman, C. B. (2002). Derivative word forms: What do learners know? TESOL Quarterly, 36(2), 145. https://doi.org/10.2307/3588328

Shabanpour, M. \& Marzban, A. (2015). The effect of task complexity on iranian pre-intermediate EFL learners' incidental learning of grammatical collocations through reading. Theory and Practice in Language Studies, 5(3), 590. https://doi.org/10.17507/tpls.0503.19

Sidek, H., \& Rahim, H. A. (2015). The role of vocabulary knowledge in reading comprehension: A cross-linguistic study. Procedia - Social and Behavioral Sciences, 197, 50-56. https://doi.org/10.1016/j.sbspro.2015.07.046

Stockwell, R., \& Minkova, D. (2001). English words: History and structure. Cambridge University Press.

Trevian, I. (2015). English suffixes: Stressassignment properties, productivity, selection and combinatorial processes. Peter Lang.

Vaughn, S., Martinez, L. R., Linan-Thompson, S., Reutebuch, C. K., Carlson, C. D., \& Francis, D. J. (2009). Enhancing social studies vocabulary and comprehension for seventhgrade English language learners: Findings from two experimental studies. Journal of Research on Educational Effectiveness, 2(4), 297-324. https://doi.org/10.1080/19345740903167018

Valcourt, G., \& Wells, L. (1999, November). Mastery: A university word list reader. Retrieved August 30, 2020, from http://www.teslej.org/wordpress/issues/volume4/ej14/ej14r3/

West, M. (1953). A general service list of English words. Longman.

Wyra, M., \& Lawson, M. J. (2018). Foreign language vocabulary learning using the keyword method: Strategy and meta-strategy knowledge. The Language Learning Journal, 46(5), 605-621. https://doi.org/10.1080/09571736.2018.150313 8

Xue, G., \& Nation, P. (1984). A university word list. Language Learning and Communication, 3, 215-229.

\section{Appendix \\ New Levels of Derivational Suffixes Based on COCA Academic}

Level 1 : -(at)ion, -able/-ible, -acy/-asy/-cy, -al/-ial/-ual, -ance/-ence, -ar/-er/-or, -ary/-ory, -ate, -en, ful, -ic, -ify, -ist, -ise/-ize, -ive, -ity/-ty, -ly, -sion/-tion/-xion, -ment, -ness, -ous, -wise

-al, -ism, -(r)y, -ary/-ery/-ory, -ship, -ure, -ian/-an, -ate, -ly, -less, -ed, -y.

Level $3 \quad$ : -age, -ant/-ent, -ie/-y, -hood, -ician, -en, -ese, -i, -s. 